
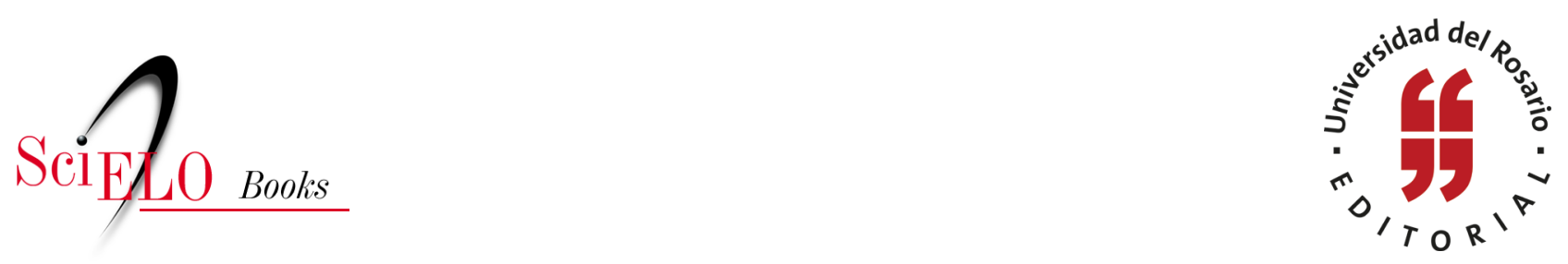

\title{
32. Tita, la del cabello dorado-derramado
}

\author{
César Augusto Tapias Hernández
}

TAPIAS HERNÁNDEZ, C.A. Tita, la del cabello dorado-derramado. In: Historias de familia: Etnografía delirante sobre el amor, la violencia y las drogas [online]. Bogotá: Editorial Universidad del Rosario, 2014, pp. 139-141. Textos de ciencias humanas collection. ISBN: 978-958-738-543-4.

https://doi.org/10.7476/9789587385434.0033.

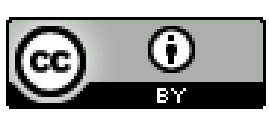

All the contents of this work, except where otherwise noted, is licensed under a Creative Commons Attribution 4.0 International license.

Todo o conteúdo deste trabalho, exceto quando houver ressalva, é publicado sob a licença Creative Commons Atribição 4.0.

Todo el contenido de esta obra, excepto donde se indique lo contrario, está bajo licencia de la licencia Creative Commons Reconocimento 4.0. 


\section{Tita, la del cabello dorado-derramado}

Everybody can't go to school a lot. Some people have to live, man.*

Philippe Bourgois, In search of respect. Selling crack in El Barrio

- Me gustaría estudiar; pero me da pereza, como me mantengo mucho con mis amiguitas. Además, entiendo poco, porque... como no presto atención y, además, el iprofe me tiene bronca!

- ¿Cómo es eso?

- Si él pregunta algo, yo contesto primero que todos; pero él no me pone atención... Y si mis amiguitas me hablan en clase y yo les converso... Ahí sí me ve... A veces me regaña delante de todos y entonces todos me gozan... Y empiezan hablar de mí, y a mí eso no me gusta... Me da rabia, sobre todo cuando me gozan y hablan a mis espaldas. Me siento mal... pero ¿yo por qué voy a quedarme callada cuando me gritan o me hacen algo?

- ¿Por ejemplo?

-Por ejemplo... En estos días una niña me quería pegar, y yo fui y le contesté que me diera, pues. Me empujó y yo ahí mismo la agarré del pelo... Al otro día ella y yo tuvimos que ir con la mamá ante el director...

A la niña de rizos de oro de cabello dorado-derramado sobre los hombros de mil quilates en pura sonrisa con ojos profundos y aventurados... Y de decisiones decididas al parecer (que a veces hasta parece contestoncita...). A ella dizque no le gustan los mariguaneros. Esa niña es Tita, la menor de las mujeres de "La Cucha” (y el tío $\mathrm{H})$.

* "No todo el mundo puede ir a la escuela. Algunas personas tienen que vivir, hombre". 
A Tita un computador le parece interesante. Le gustaría incluso estudiar eso... - Sí, es que de pronto no puedo estudiar medicina.

Solo a eso le gustaría ir a la universidad... A estudiar medicina. Por ahora va para sexto grado y le gustaría meterse a hacerlo en el Colegio El Rosal... La falla es que es un colegio de monjas y hay que pagar mensualidad; pero es que del Rosal mandan a los hospitales a las peladas de décimo grado cuando les toca eso del Vigía de la Salud... Solo por eso Tati iría al Rosal, por ir a los hospitales como le toca a Natalia, una amiguita suya. Un día Tita fue a Comfama, acompañando a Natalia a su clase de computadores y fue ahí cuando se dio cuenta de que le gustaría aprender eso también: computadores...

- Sí, es que de pronto no puedo estudiar medicina.

-Pelaíta, si le gusta eso y no tiene plata, dígale al profe de computadores que la deje entrar de vez en cuando. A lo mejor resulta usted más interesada que cualquiera de los que pagan... Piense qué quiere hacer... y averigüe... y cuente... y hable. Sea entrona como los de aquí - le dije yo.

Que ha pensado en el Colegio Alfredo Cook, me dijo también... que porque hay buenos profesores, según le dicen; pero el problema es que ahí entra mucho "mariguanero".

Ya he contado que en casa de Tita se vende yerba, y se fuma... y ella insiste en que a pesar de eso no le gustaría fumar nunca... Tita apenas tiene once años cuando escribo esta historia... Y ya está como decididita. Así por el estilo parece tener muchas más cosas claras... Por lo menos, las reflexiona.

Y en medio de esa claridad en la que al parecer se define, dice Tita que le gustaría ponerle atención a la clase, que quisiera ser más aplicada, pero es que las amigas le hablan y ella no se aguanta; sin embargo, me dice que va a intentar guardar silencio. Intentar guardar silencio. Intentar. Guardar. Silencio. Como si fuera un ángel. SilenCiO.

El silencio es el hechizo del demonio, y cuanto más se calla, tanto más peligroso es el demonio; pero el silencio es también la conciencia del encuentro particular con la divinidad. Decía Kierkegaard, por allá en 1843. Y la Tita mirando un punto perdido, me va contando de sus ideas e intenciones, mientras de fondo la rutina de la casa:

-Una bolsita, mona.

Por la ventana, la bolsita de baretica, a seiscientos pesos cada bolsita...

El feo las arma y, de ñapa, regala un par de papeles smoking para enrollar... 
Viendo esa vuelta todos los días... Tita sabe que la gente gasta en eso DEMASIADO:

—Es una bobada fumar mariguana — dice—, quedan como bobos después de que fuman eso... ¡ Y toda la plata que se gastan...!

Tita la del cabello derramado

Hoy de blusa azul

Y mejillas también azules

Tiene un par de mirellitas grandes en las mejillas... Piensa de pronto en volver a la clase, en acercársele el profe de la escuela y pedirle que la cambie de puesto.

-Que me ponga donde sea pero sola, adelante o en el medio... i pero sola! Y que ojalá el profe ya no la regañe más — dice-. ¡Al menos no delante de todos!

- Haga las tareas — le digo a la Tita - Ponga atención, y si el profe es inteligente, lo notará.

-Y si no lo es, ¿qué?

-Ni se le ocurra decirle al profe que no es inteligente — le advierto-. Más bien, déjelo que muera engañado.

Y SE RÍE TiTA. Mil quilates en pura sonrisa.

Los dientes de Tita son blancos-blancos.

Y me ponen a pensar en la bata blanca de los médicos.

Debe de verse linda esta niña como médica: vestida de bata blanca la doctora Tita Tales.

De cabello de oro y dientes blancos como la bata, como su esperanza. 